\title{
Die verhouding tussen Ou-Testamentiese wetenskap en Teologiese interpretasie van die Bybel: Handelinge 8:26-40 as gevallestudie
}

\begin{tabular}{|c|c|}
\hline \multicolumn{2}{|c|}{$\begin{array}{l}\text { Author: } \\
\text { Anneke Viljoen }^{1}\end{array}$} \\
\hline \multicolumn{2}{|c|}{$\begin{array}{l}\text { Affiliation: } \\
{ }^{1} \text { Department of Old } \\
\text { Testament Studies, Faculty of } \\
\text { Theology, University of } \\
\text { Pretoria, South Africa }\end{array}$} \\
\hline \multicolumn{2}{|c|}{$\begin{array}{l}\text { Research Project Registration: } \\
\text { Project Leader: A.B. Geyser- } \\
\text { Fouché (D) } \\
\text { Project Number: } 1258230\end{array}$} \\
\hline \multicolumn{2}{|c|}{$\begin{array}{l}\text { Description: } \\
\text { Dr Viljoen is participating in } \\
\text { the research project, 'Second } \\
\text { Temple Literature and } \\
\text { Qumran', directed by Dr } \\
\text { Ananda Geyser-Fouché, } \\
\text { Department of Old Testament } \\
\text { Studies, Faculty of Theology, } \\
\text { University of Pretoria. }\end{array}$} \\
\hline \multicolumn{2}{|c|}{$\begin{array}{l}\text { Corresponding author: } \\
\text { Anneke Viljoen, } \\
\text { anchri@mweb.co.za }\end{array}$} \\
\hline \multicolumn{2}{|c|}{$\begin{array}{l}\text { Received: } 20 \text { Dec. } 2016 \\
\text { Accepted: } 17 \text { Mar. } 2017 \\
\text { Published: } 19 \text { June } 2017\end{array}$} \\
\hline \multicolumn{2}{|c|}{$\begin{array}{l}\text { How to cite this article: } \\
\text { Viljoen, A., 2017, 'Die } \\
\text { verhouding tussen Ou- } \\
\text { Testamentiese wetenskap en } \\
\text { Teologiese interpretasie van } \\
\text { die Bybel: Handelinge } \\
\text { 8:26-40 as gevallestudie', } \\
\text { HTS Teologiese Studies/ } \\
\text { Theological Studies 73(1), } \\
\text { a4496. https://doi.org/ } \\
\text { 10.4102/hts.v73i1.4496 }\end{array}$} \\
\hline \multicolumn{2}{|c|}{$\begin{array}{l}\text { Copyright: } \\
\text { (C) 2017. The Author } \\
\text { Licensee: AOSIS. Thi } \\
\text { is licensed under the } \\
\text { Creative Commons } \\
\text { Attribution License. }\end{array}$} \\
\hline \multicolumn{2}{|l|}{ Read online: } \\
\hline 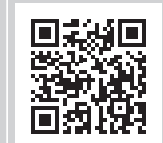 & $\begin{array}{l}\text { Scan this QR } \\
\text { code with your } \\
\text { smart phone or } \\
\text { mobile device } \\
\text { to read online. }\end{array}$ \\
\hline
\end{tabular}

\begin{abstract}
Theological interpretation of the Bible represents a broadening of the hermeneutical approaches available to an interpreter of Bible texts. As such, Theological interpretation of the Bible opens up the possibility to investigate and explore more aspects of the Bible text. Especially aspects that are in line with the nature of the Bible text such as Scriptures of the church as well as the illocutionary force of these texts. After a few introductory remarks concerning Theological interpretation of the Bible, three questions guided reflection on defining theological interpretation: first, Why Theological interpretation of the Bible?; second, What is Theological interpretation of the Bible not?; and third, What is Theological interpretation of the Bible? Last mentioned was explored on the basis of a focus text, namely Acts 8:26-40 that served as a case study.
\end{abstract}

\section{Inleiding}

Die histories kritiese benadering tot die Bybelteks het oor die algemeen, sedert die ontstaan daarvan en tydens die vorige eeu, die werkruimte binne die Ou-Testamentiese wetenskap gedomineer (Green 2011:12), veral voor die redelik onlangse ontstaan van alternatiewe hermeneutiese benaderings tot die Bybel (Cheung 2014:51). Hierdie tydperk van dominansie van die historiese kritiek was van so 'n aard dat Ricoeur metafories daarna verwys het as 'n woestyntyd (Nathan 2014:16; Vanhoozer 2008:16). Historiese kritiek $^{1}$ bied egter nie 'n voldoende omvattende benadering tot die teks nie aangesien dit net sekere aspekte van die teks ontgin terwyl ander aspekte daarvan onontgin gelaat word (kyk ook Green 2007:3; Treier 2008:16).

Teologiese interpretasie van die Bybel bied 'n hermeneutiese verruiming waarbinne meer aspekte van die teks ondersoek en ontgin kan word. Veral aspekte van die teks wat in ooreenstemming is met die aard van die Bybelteks as Skrif van die kerk asook met die illokusionêre $\mathrm{krag}^{2}$ van die teks. Die Bybelteks is ' $n$ teologiese geskrif en wil lesers beweeg in terme van die teologiese perspektief van die teks. Ander alternatiewe hermeneutiese benaderings tot tekste is ook nie altyd voldoende om as onderbou te dien vir 'n spesifieke Christelike hermeneutiese benadering tot die Bybelteks nie. Die filosofiese onderbou van byvoorbeeld dekonstruksie is moeilik versoenbaar met ' $n$ Christelike hermeneutiese benadering (Vanhoozer [1998] 2009:122-126; sien ook Adam et al. 2006:8, 10). Daarom is die ontwikkeling van Teologiese interpretasie in terme van die metodologiese onderbou daarvan, na my mening, 'n nodige en tydige projek - iets waaraan daar in hierdie sowel as 'n volgende artikel (Viljoen 2017) aandag gegee word. In die huidige artikel word aandag gegee aan die definiëring van Teologiese interpretasie en wat hierdie benadering tot die teks prakties behels.

Daar is groot eenstemmigheid onder beoefenaars van Teologiese interpretasie van die Bybel, naamlik dat dit nie 'n eenvormige benadering tot die Bybelteks met uiteenlopende metodologiese en ander kenmerke behels nie (kyk onder andere Carson 2011:187; Green 2011:12-14; Meadowcroft 2013:1). Derhalwe verteenwoordig my gedagtes hier nie 'n omvattende refleksie op die hele beweging van Teologiese interpretasie nie, maar eerder inleidende gedagtes rondom my eie verstaan van hierdie benadering tot die Bybelteks asook gedagtes rondom die verhouding

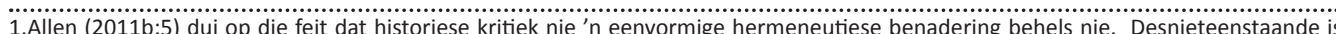
daar tot ' $n$ groot mate gedeelde ingesteldhede, vertrekpunte, voorveronderstellings en praktyke wat Bybelwetenskappe onder die invloed van historiese kritiek kenmerk. Carson (2011:200-202) waarsku teen die tendens wat by teologiese interpretasie voorkom om histories kritiese benaderings tot die teks eenduidig negatief te evalueer en bepleit 'n hermeneutiese benadering wat dit regkry om historiese sowel as teologiese elemente van die teks onder die outoriteit van die Skrif in die hermeneutiese proses te integreer (Carson 2011:207).

2.'n Bondige definisie van die begrip illokusionêre krag van 'n teks of spraakhandeling is soos volg: The illocutionary force of an utterance is the speaker's intention in producing that utterance. An illocutionary act is an instance of a culturally-defined speech act type, characterised by a particular illocutionary force; for example, promising, advising, warning (Illocutionary force nd.). 
tussen spesifiek Ou-Testamentiese wetenskap en Teologiese interpretasie van die Bybel.

\section{Wat is Teologiese interpretasie?}

Drie vrae begelei hierdie nadenke rondom die definiëring van Teologiese interpretasie: eerstens, Waarom Teologiese interpretasie van die Bybel?; tweedens, Wat is Teologiese interpretasie van die Bybel nié?; en derdens, Wat ís Teologiese interpretasie van die Bybel? ${ }^{3}$

\section{Waarom Teologiese interpretasie van die Bybel?}

Vanhoozer (2008:17) merk dat twee krisisse, onderskeidelik deur Aufklärung en post-Aufklärung ontwikkelings in bybelse interpretasie, ontketen is. Teologiese interpretasie van die Bybel wil op hierdie krisisse reageer ten einde Bybelwetenskappe se fundamentele teologiese onderbou te herwin wat in sommige gevalle neig om onder Aufklärung en post-Aufklärung invloede genegeer te raak. Die eerste is die waterdigte onderskeid wat daar ontstaan het tussen die Bybelwetenskappe en teologie (kyk ook Green 2011:12). Hierdie waterdigte onderskeid manifesteer in die dikwels skerp onderskeid tussen eksegese en teologisering (sien ook Carson 2011:192-196; Green 2011:14-15; vgl. Fowl [1998] 2008:9-10). Dit kan verklaar word in terme van die voortsetting van Lessing ([1777] 2005:87) se aaklige diep kloof wat skerp onderskeid tref, tussen, enersyds, rede met historisiteit wat toeganklik en vasstelbaar is in die publieke sfeer, en andersyds, geloof wat in die private sfeer waardeer word (Vanhoozer 2008:17). Die gevolg van hierdie invloed is dat die Bybelteks benader is as ' $n$ bron vir die rekonstruksie van menslike geskiedenis en godsdiens eerder as getuienis tot die teenwoordigheid en handelinge van God in die geskiedenis. Om die Bybelteks te reduseer tot ' $n$ bron of bewysstuk van die natuurlike of menslike fenomene wat agter die teks lê, is om die aandag van die Bybelteks se karakter as getuie tot God se handelinge te deflekteer (Vanhoozer 2008:18). Teologiese interpretasie wil die Bybelteks bevry van die beperkings van streng historiese benaderings tot die teks wat enige getuie daarvan tot bonatuurlike invloede ontken en mis lees onder die invloed van post-Aufklärung aannames oor die aard van geskiedenis (Carson 2011:188). Met ander woorde, die fokus van bybelse interpretasie was, onder die invloed van die Aufklärung, op menslike agentskap eerder as op die Bybel as getuie tot Goddelike agentskap gefokus. ${ }^{4}$

Die tweede krisis is kenmerkend van post-Aufklärung ontwikkelings in bybelse interpretasie. Hier word eksegese met ideologiekritiek verwar. Waar die versoeking vir histories-kritiese benaderings tot die Bybelteks is om slegs dun beskrywings te gee van die wêreld 'agter die teks' of die komposisiegeskiedenis van die teks, is die versoeking van postmoderne ideologiekritiek om die belange van die leser

3.Ek het Vanhoozer (2008:15-24) se inleidende gedagtes om duidelikheid te kry ten opsigte van die definiëring van teologiese interpretasie van die Bybel so waardevo gevind dat ek hom hier in my drie vrae nadoen (kyk ook Allen 2011b:1-7).

4.Vir meer hieroor sien Viljoen (2017). en/of leesgemeenskap 'voor die teks' op die teks te projekteer (Vanhoozer 2008:19; [1998] 2009:98-187). So word die karakter van die Bybelteks as die spreke van 'n ander ontneem. Om enersyds te fokus op die wêreld 'agter die teks', en andersyds op die wêreld 'voor die teks' is om die aandag van die hermeneut af te lei van dít waartoe die teks getuie lewer (Green 2007:2; Vanhoozer 2008:20). Op albei hierdie uitdagings wil Teologiese interpretasie 'n gebalanseerde teologiese respons bied. Die ongemak van Teologiese interpretasie met histories- of ideologie-kritiese benaderings is nie met die benaderings op sigself nie, maar met die beperkende geneigdheid van 'n groot aantal kontemporêre hermeneutiese benaderings ten opsigte van óf die filosofiese naturalisme van historiese kritiek óf spekulatiewe interpretasies, gedryf deur die onderskeie agendas van ideologiekritiek (Carson 2011:187-192).

Allen (2011b:1-2) merk op dat die pogings van Teologiese interpretasie spesifiek teologies is omdat dit interpretasie van of kommentaar op die heilige Skrifte van die kerk is (kyk ook Moberly 2009:162). Teologiese interpretasie van die Bybel is 'n modus van kritiese omgang met die Skrif (Green 2007:1), gerig op kennis van God (Vanhoozer 2005:24). Voor ons egter poog om Teologiese interpretasie van die Bybel meer genuanseerd te definieer, is dit goed om dit eers te bedink in terme van wat dit nié is nie (vlg. Vanhoozer 2008:16-17; Moberly 2011:173).

\section{Wat is Teologiese interpretasie van die Bybel nié?}

Teologiese interpretasie van die Bybel is nie om konfessionele voorveronderstellings of 'n teologiese sisteem op die teks te projekteer nie (Vanhoozer 2008:16). Teologiese interpretasie van die Bybel het geweldige waardering en ruimte vir die konfessionele en teologiese oortuigings van die hermeneut tot so 'n mate dat Bowald (2010:175) 'n maksimale benadering tot die hermeneutiese handeling van lees voorstel: Dit is onvermydelik, gepas en selfs noodsaaklik dat hermeneute hulle konfessionele en teologiese oortuigings na die leesproses bring (kyk ook Adam et al. 2006:9-10, Carson 2011:196-197). Nieteenstaande hierdie openheid waak Teologiese interpretasie teen die drievoudige kwesbaarheid van 'n pre-kritiese omgang ten opsigte van konfessionele en teologiese voorveronderstellings, naamlik om eerstens nie die Bybelteks in sy historiese konteks ernstig te neem nie; tweedens, om nie die teks binne die teologie van onderskeidelik die Ou of Nuwe Testament as deel van die kanon te integreer nie; en derdens, om 'n onvoldoende kritiese bewustheid van of ingesteldheid teenoor die hermeneut se voorveronderstellings en teologiese standpunte te handhaaf (Wright in Vanhoozer 2008:16; kyk ook Carson 2011:197-202).

Teologiese interpretasie van die Bybel is ook nie om 'n algemene hermeneutiek of teorie van interpretasie op die Bybelteks te projekteer nie. Dit is juis omdat sommige hermeneutiese vraagstukke teologiese insigte vereis en nie beperk kan word tot die antwoorde wat 'n algemene 
hermeneutiek kan bied nie (Vanhoozer 2008:17). Teologiese interpretasie is verder ook nog nie bloot 'n vorm van historiese, literêre of sosiologiese kritiek wat op die onderskeie wêrelde 'agter', 'van' of 'voor' die Bybelteks fokus nie (Vanhoozer [1998] 2009:17). Allen (2011b:5-6) bevestig dat Teologiese interpretasie inderdaad met groot vrug van die insigte van die Bybelwetenskappe en historiese kritiek asook postmoderne leesstrategieë gebruik kan (selfs behoort te) maak sonder om gereduseer te word tot hierdie benaderings tot die teks (sien ook Adam et al. 2006:7; Van Hecke 2014:81). Vir Treier (2008:16) is histories-kritiese benaderings tot die teks eerder voorbereidend tot interpretasie omdat dit nie 'n omvattende hermeneutiese benadering tot die Bybelteks behels wat die rykdom van die teologiese perspektief wat in die Skrif tot uitdrukking kom, kan ontsluit nie.

\section{Wat ís Teologiese interpretasie van die Bybel?}

Die narratief in Handelinge 8:26-40, Filippus se ontmoeting met die Etiopiese amptenaar, ${ }^{5}$ verteenwoordig, na my mening, 'n goeie vertrekpunt waaruit rigtingwysers ${ }^{6}$ vir Teologiese interpretasie ontgin sou kon word. Dit is natuurlik nie die enigste teks wat ontgin sou kon word nie (kyk bv. Fowl [1998] 2008; Allen 2011a; Green \& Meadowcroft 2013). Aangesien Filippus in die narratief self 'n teologiese uitleg gee van die Ou-Testamentiese teks (Jes 53:7-8) wat die Etiopiese amptenaar lees, ${ }^{7}$ verteenwoordig hierdie narratief verder, na my mening, ook nog 'n goeie vertrekpunt in terme van nadenke rondom die verhouding tussen Ou-Testamentiese wetenskap en Teologiese interpretasie van die Bybel. Drie bewegings in die teks (vgl. MacArthur 1973) het na my mening die vermoë om die praktyk en uitdagings van kontemporêre Teologiese interpretasie toe te lig. Uiteraard was dit nooit die bedoeling van die outeur van Handelinge om met hierdie vertelling rigtingwysers vir Teologiese interpretasie aan te bied nie, maar ek is van oortuiging dat die beginsels wat in die teks geillustreer word steeds geld en derhalwe as rigtingwysers vir kontemporêre Teologiese interpretasie van die Bybel kan dien. My omgang met hierdie spesifieke teks dien hier dan ook terselfdertyd as 'n illustrasie van die moontlikhede van Teologiese interpretasie van die Bybel. $^{8}$ Die drie bewegings wat hier ontgin sal word, is die voorbereiding,

5.'n Kollega, Hugh Jenkins (1989), het my op die gedagte van hierdie spesifieke teks gebring deur sy ongepubliseerde werk rondom die vraag na die lydende kneg in Jesaja met my te deel.

6.Ek is dank verskuldig aan Trevor A. Hudson vir sy gedagtes rondom die ontginning van'n Bybelteks vir' $n$ praktiese model. Tydens die sewende module (Aug. 2016) van
die Jesuïete instituut van Suid-Afrika se opleiding in geestelike begeleiding (SDT die Jesuïete instituut van Suid-Afrika se opleiding in geestelike begeleiding (SDT $2015-2016)$, het hy sy nadenke, gebaseer op Johannes 20:11-18, aangebied om ' $n$
model vir die bediening van geestelike begeleiding in tye van pyn en lyding te ontgin.

7.Die fokus is hier nie op die Jesaja-teks binne sy Ou-Testamentiese konteks nie, maa juis op Filippus se interpretasie daarvan in konteks met die Jesus-gebeure. Dat die Ou-Testamentiese teks (in Jesaja) hier aan die begin van die hermeneutiese tradisie van die kerk binne die konteks van die Jesus-gebeure geïnterpreteer word, open die moontlikheid vir kontemporêre hermeneute om Ou-Testamentiese tekste so te kan interpreteer. Dit is juis een van die oogmerke van Teologiese interpretasie warvoo daar'n saak uitgemaak probeer word deur die keuse van die Handelinge-teks as die fokusteks vir die artikel.

8.Ter wille van bondigheid word hier op die narratief in Handelinge 8:26--40 gefokus sonder om eksplisiet aandag aan die teologisering van die skrywer van (Lukas-) Handelinge te gee. Dit is ' $n$ aspek van die teks wat uiteraard ook in Teologiese Handelinge te gee. Dit is ' $n$ aspek van die teks wat uiteraard ook in Teologiese
interpretasie aandag sou kon geniet (vgl. Allen 2011b:8 se drie fasette van Teologiese interpretasie). die aanbieding en die respons ten opsigte van Teologiese interpretasie.

\section{Die voorbereiding}

Waar die inisiatief vir die handelinge in die narratief gesetel is, is die eerste toeligting vir kontemporêre Teologiese interpretasie vanuit hierdie fokusteks (Hand 8:26-40). ${ }^{9}$ Dit is 'n engel van die Here wat vir Filippus aanspreek ${ }^{10}$ en die opdrag gee om hom klaar te maak om teen die middag ${ }^{11}$ na die bestemde plek te gaan. In vers 29 word die spreker as die Gees geïdentifiseer. Die teks lei tot besinning rondom die verband tussen die engel (v. 26) en die Gees (v. 29) wat hier nie hoef ontgin te word vir die doeleindes van die interpretasie nie. Die fokus van hierdie interpretasie is op die engel en die Gees wat, vir alle praktiese doeleindes albei die aksie of handeling van God verteenwoordig (vgl. Fowl [1998] 2008:19-21 vir nadenke rondom die invloed van hermeneutiese doeleindes op interpretasie). Die beginsel wat uit die narratief ontgin kan word, handel rondom die agentskap van God $^{12}$ in kontemporêre Teologiese interpretasie. Dit is God wat deur die Gees die inisiatief neem. Suksesvolle Teologiese interpretasie is afhanklik van die inisiatief van die Heilige Gees.

Naas die inisiatief van God, in die teks verteenwoordig deur die engel en die Gees wat aan Filippus opdragte gee, speel die gewilligheid en bekwaamheid van die hermeneut 'n belangrike rol in die heuristiese proses. Goddelike en menslike agentskap sluit mekaar nie uit in die narratief van Handelinge nie en ook nie in Teologiese interpretasie nie. Filippus is gewillig sowel as bekwaam om die Here se opdrag uit te voer. Sy gewilligheid word geillustreer deur sy gehoorsaamheid aan die eerste opdrag van die engel asook sy reaksie op die tweede opdrag van die Gees wanneer daar in die teks vermeld word dat hy na die wa waarheen die Gees hom stuur, hardloop. Filippus se bekwaamheid word betuig wanneer die Gees geen verdere opdragte gee nadat hy by die wa aangekom het nie; wanneer Filippus hoor waaruit die Etiopiër voorlees weet hy dadelik hoe om hom te benader. Dit is heel waarskynlik omdat hy goed geoefen was in die vaardigheid om tekste te interpreteer en aan 'n gehoor uit te lê soos wat Handelinge $8: 4-5^{13}$ van hom getuig. Verskeie voorstanders van Teologiese interpretasie wys op die noodsaak van die leer sowel as die lewe van die hermeneut vir geloofwaardige Teologiese interpretasie (kyk Briggs [2010] 2012; Fowl [1998] 9.Alle verdere versverwysings dui op Handelinge 8:26-40.

10.Die diatese van albei die frases wat die engel se aksie van praat uitdruk, is aktief.

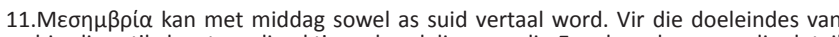
hierdie artikel wat op die aktiewe handeling van die Engel eerder as op die detail van die boodskap fokus, maak die interpretasiemoontlikhede nie 'n groot hermeneutiese verskil nie. Dit sou in ander hermeneutiese kontekste met ande doelwitte moontlik' $n$ beduidende invloed op interpretasie kon hê en daarom moet die hermeneut bewus wees van die onderskeie interpretasiemoontlikhede en die effek wat dit op interpretasie sou kon hê (vgl. Fowl [1998] 2008:19-21).

12.Bowald ([2007] 2016) het die kartering van menslike en Goddelike agentskap in verskeie hermeneutiese modelle ondersoek en lewer ondersteunende nadenke rondom die verband tussen die twee.

13. Handelinge 8:4-5 (Nuwe Afrikaanse Vertaling - NAV): 'Die gelowiges wat uitmekaar gejaag is, het so ver as wat hulle gegaan het, die evangelie verkondig. ${ }^{5} \mathrm{So}$ het dit gebeur dat Filippus by'n stad in Samaria gekom het en Christus daar verkondig het.' 
2008:178-205; Vanhoozer [1998] 2009:367-441). Fowl ([1998] 2008:12-13) benadruk die rol van Christelike formasie ${ }^{14}$ binne geloofsgemeenskappe ten einde seker te maak dat Bybellesers die nodige praktiese (hermeneutiese) wysheid bekom om die Skrif op so 'n manier te lees dat die roeping om as individue en gemeenskappe ten volle voor God te leef en te aanbid, gedien sal word (kyk ook Vanhoozer [1998] 2009:329-377 vir meer oor die verantwoordelikhede van 'n getroue lees van die Bybelteks).

Ook die Etiopiese amptenaar vertoon hermeneutiese deugde deurdat hy die teks (Jes 53:7-8) ywerig ondersoek (kyk Briggs [2010] 2012 asook Vanhoozer [1998] 2009:376-378 vir meer oor interpretatiewe deugde). Sover dit teologiese interpretasie aangaan, is die deugde van ywerige studie dat, alhoewel volledige kennis van die teks nie noodwendig tot die leser se beskikking is nie, hy of sy wel voldoende literêre kennis tot sy of haar beskikking het om 'n respons ten opsigte van die teksonderwerp te kan maak (kyk Vanhoozer [1998] 2009:281350). Die Etiopiese amptenaar openbaar verder ook nog die belangrike deugde van nederigheid in sy lees van die teks. Hy is leergierig en skroom nie om vir hulp te vra in sy uitleg van die teks (v. 31) nie. Die Etiopiër se onbeskroomdheid en leergierigheid herinner voorstanders van Teologiese interpretasie daaraan dat ander hermeneutiese benaderings tot die Bybelteks ook 'n bydrae tot die verstaan van die teks kan lewer en derhalwe kan insigte van ander hermeneutiese benaderings met groot vrug in die projek van Teologiese interpretasie benut word. Carson (2011:200-202) waarsku veral teen die oënskynlike negatiwiteit van Teologiese interpretasie van die Bybel teenoor histories-kritiese benaderings tot die Bybelteks terwyl Heringer (2013) pleit vir dieper nadenke rondom die historisiteit van die Bybelteks en hoe om daarmee om te gaan binne die hermeneutiese raamwerk van Teologiese interpretasie (kyk ook Allen 2011b:4-6b).

\section{Die aanbieding}

'n Verdere beginsel uit die teks behels die aanbieding van Teologiese interpretasie. Met aanbieding word bedoel die konteks waarbinne en doeleindes waartoe Teologiese interpretasie van die Bybel verbind is. Die belangrikheid van die meelees-gemeenskap in Teologiese interpretasie kan nie oorbeklemtoon word nie. Soos wat die Gees Filippus stuur om die Bybelteks sáám met die Etiopiese amptenaar te lees, is die meelees-gemeenskap, die kerk, 'n gawe van God. In die Etiopiër se antwoord 'Hoe sou ek kon as niemand my daarin lei nie?' [outeur se eie vertaling uit Grieks], op Filippus se vraag 'Verstaan u wat u lees?',15 word dieselfde woord vir 'lei'

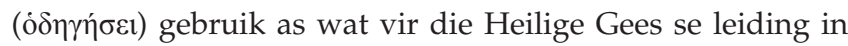
Johannes 16:13 gebruik word. Teologiese interpretasie is 'n hermeneutiese benadering wat nadruk plaas op die konteks van interpretasie binne die hermeneutiese ruimte van geloof en kerk (Treier 2008:16; Green 2011:14; Van Hecke 2014:70-72) wat ' $n$ invloedsfeer van die Heilige Gees is.

14.Christelike formasie (spiritual formation) is 'n subdissipline van geestelike begeleiding (spiritual direction). Vir meer hieroor sien Viljoen (2016).

15.'n Woordspeling in die Grieks (De Villiers 1983b).
Soos reeds genoem, koester Teologiese interpretasie van die Bybel ' $n$ openheid vir die konfessionele verbintenisse van die hermeneut. Dit maak dit moontlik vir die hermeneut om uit 'n ryker en meer diverse spektrum van perspektiewe te put (kyk ook Moberly 2011:184-185). Adam et al. (2006:9) verduidelik dat een van die groot verskille tussen die Bybelse teologie-beweging en Teologiese interpretasie die verstaan is van hermeneutiek in terme van teologiese en konfessionele voorveronderstellings. Waar argumente binne die Bybelse teologie-beweging dikwels rondom die aanspraak op onpartydige historiese ondersoeke en die aard van verstaan sentreer, is Teologiese interpretasie gemaklik dat die kerk se leertradisie die waarheid wat daarin tot uitdrukking kom, komplimenteer. Inteendeel, deur die relevansie van die hermeneutiese bydraes van interpreteerders deur die eeue te erken, bestaan die moontlikheid om uit 'n ryker en meer diverse spektrum van perspektiewe te put. Die kerk en kerklike leertradisies maak dus 'n belangrike bydrae in die diskoers rondom Teologiese interpretasie (Fowl [1998] 2008:2-9); Adam et al. 2006:9). Met ander woorde, die gevolg hiervan vir Teologiese interpretasie is dat teologie ook eksegese beïnvloed; die hermeneutiese pad loop nie net eendimensioneel van eksegese na teologie nie (Bowald 2010:164; Green 2011:15-16). Voorstanders van Teologiese interpretasie hanteer die teologiese dimensies van die teks nie as 'n sekondêre stap nadat vasgestel is wat die teks beteken nie. Die teologiese dimensie van die Bybelteks deurspek alle hermeneutiese pogings waardeur gestrewe word om tot verstaan te kom asook pogings om die betekenis wat in die proses onderskei is te artikuleer (vgl. Adam et al. 2006:9).

Dit is omdat die basis van konfessionele en teologiese oortuigings, volgens Bowald (2010:175), hulle oorsprong in die horison van Goddelike handeling het wat dit omsluit. Dit is ook met behulp van konfessionele en teologiese oortuigings waarmee hermeneute hulle leesstrategieë oordeel. Ricoeur is byvoorbeeld gemaklik in die oortuiging dat geloofsvoorveronderstellings nie in die pad van 'n kritiese hermeneutiese ingesteldheid staan nie; geloof en kritiese denke sluit mekaar nie uit nie (Moyaert 2014:41). Die hermeneutiese sirkel begin immers by die eerste naïveté (Moyaert 2014:42). Ook vir Gadamer (in Vanhoozer 2014:4), kom die hermeneut nie los van sy of haar voorveronderstellings nie. Hermeneutiek behels vir Gadamer iets soos die opvoer van 'n drama - om die toneel ernstig op te neem is om 'van binne' te interpreteer; die hermeneut is ' $n$ aktiewe deelnemer wat sy of haar rol in die toneelstuk speel. ${ }^{16}$

Moberly (2011:185-186) maak egter 'n paar ondersteunende opmerkings ten opsigte van die omgaan met konfessionele voorveronderstellings binne die dissipline van Teologiese interpretasie van die Bybel. Eerstens, die erkenning dat die Bybel, en spesifiek die Ou Testament, ook hermeneuties

16.Jeanrond (1991:9-10) verduidelik die verskil tussen Gadamer wat 'verstaan' sien as 'n oomblik waarin waarheid sigself manifesteer eerder as die suksesvolle as 'n oomblik waarin waarheid sigself manifesteer eerder as die suksesvolle toepassing van gesofistikeerde metodologieë, en Ricoeur wat metodologiee ondersoek wat weerstand bied teen die distorsies van ideologie ten einde tot beter verstaan te kan kom. Moberly (2011:2) sien in Ricoeur sowel as Gadamer se belangstelling in die bydrae van die leser se tradisies en belange tot die hermeneutiese proses, die moontlikheid dat Teologiese interpretasie se positiewe waardering van geloofsvoorveronderstellings ' $n$ verruimende invloed binne die ruimte van die Bybelwetenskappe kan hê. 
benader kan word sonder die voorveronderstelling van die noodwendige integrasie van die Christelike resepsie van die teks, maak 'n produktiewe diversiteit moontlik in terme van die benadering en doel van Teologiese interpretasie. Teologiese interpretasie se benadering en doel is spesifiek om deur die lees van die Bybelteks tot die lewe van die kerk en die voeding daarvan by te dra; 'n doelwit wat nie noodwendig in ander benaderings tot die teks teenwoordig is nie (kyk ook Fowl [1998] 2008:2-13). Tweedens maak die hermeneutiese beginsel om die teks 'van binne' te interpreteer 'n pluraliteit van moontlikhede oop sodat die hermeneut sou kon besluitom dieteks vanuitverskeieverwysingsraamwerke te benader. Binne die $\mathrm{Ou}$ Testament self asook in die Nuwe Testament word tekste vanuit die Ou Testament geherkontekstualiseer - iets wat ook in die fokusteks (Hand 8:26-40) gebeur. Filippus herkontekstualiseer die Jesaja-teks wat deur die Etiopiese amptenaar gelees is binne die konteks van die lewe, dood en opstanding van Jesus. Die moontlikheid bestaan dus vir 'n beoefenaar van Teologiese interpretasie dat hy of sy kan kies om die Ou-Testamentiese teks vanuit óf die voor-Christelike verwysingsraamwerk van die teks óf vanuit ander gepaste kontekste te benader (naamlik deur, onder andere, 'n verwysingsraamwerk daar te stel in terme van 'n na Nuwe-Testamentiese konteks of die konteks van die twee Testamente as kanon, ens.).

In hierdie verband is nadenke rondom die moontlikheid van ' $n$ kanoniese benadering ${ }^{17}$ ten opsigte van Teologiese interpretasie van belang. Daar is egter drie uitdagings spesifiek tot Teologiese interpretasie van die Ou Testament binne 'n kanoniese konteks waarop Moberly (2011:173-176) wys wat in ag geneem sal moet word. Eerstens moet Teologiese interpretasie van die Ou Testament rekening hou met die feit dat die Ou Testament 'n versameling voorChristelike boeke is waarvan die kanoniseringsproses grootliks voor die ontstaan van die Christelike geloof en die kerk afgehandel is. Vir die vroeë kerk (geillustreer in die fokusteks van die artikel) was die uitdaging hoe om Jesus se lewe, dood en opstanding met ' $n$ bestaande liggaam van outoritêre geskrifte in verband te bring. Dit is steeds 'n uitdaging vir kontemporêre Teologiese interpretasie. Die tweede uitdaging hang baie nou met die eerste saam. Die kerk se bewilliging van hierdie bestaande liggaam geskrifte as Christelike kanon loop parallel met die ononderbroke voortgang van hierdie selfde liggaam geskrifte as Joodse kanon. Teologiese interpretasie van die $\mathrm{Ou}$ Testament sal ook met hierdie feit rekening moet hou en, soos Moberly (2011:174-175) en Fowl ([1998] 2008:7) aandui, moontlik selfs ook uit interaksie met Joodse hermeneutiese benaderings kon put.

Die derde uitdaging het te doen met die Septuagint as Griekse vertaling van die Hebreeuse- en Aramese tekste van die Ou

17.'n Kanoniese benadering behels die openheid om die teks vanuit die verstaanskonteks van die kanon as geheel te benader. Dit sou beteken dat hermeneute wat ' $n$ Ou-Testamentiese teks eksegetiseer, byvoorbeeld Jesaja 3.7-8, wat in die fokusteks van die artikel figureer, nie hulle kennis oor die

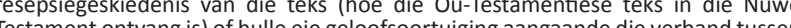
Testament ontvang is) of hulle ele geloofsoortuiging aangaande die verband tussen die Ou-Testamentiese teks en die Jesus-gebeure (hoe dit ook al gekonseptualisee word) opsy hoef te skuif in hulle omgang met die Ou-Testamentiese teks nie.
Testament. In die geval van die fokusteks lees die Etiopiese amptenaar in Handelinge 8:32-33 ' $n$ verbatim aanhaling van 'n Griekse vertaling van Jesaja 53:7-8 voor (Parsons 2008:121). Dit is die Griekse teks waarmee Filippus in sy interpretasie en uitleg daarvan werk. Moberly (2011:175) wys op drie beduidende punte in hierdie verband: eerstens, omdat die Griekse vertaling van die Ou Testament grootliks van die eerste baanbrekersvertalingsprojekte in die Weste verteenwoordig, is die Septuagint nie noodwendig altyd so afgerond en duidelik nie. Dit is ook die geval in die fokusteks, maar hier kan die onduidelikheid juis aanleiding gee tot dubbelsinnigheid wat uitnooi tot dieper nadenke oor die betekenis en interpretasiemoontlikhede van die teks. Tweedens, vertaling het noodwendig 'n interpretatiewe dimensie, maar in die geval van die Septuagint is dit dikwels duidelik dat die vertalers die inhoud van die teks doelbewus so weergee dat dit meer toeganklik sou wees vir die Hellenistiese kultuur waarbinne die vertaling diens sou doen. Derdens, die Ou Testament is hoofsaaklik deur die skrywers van die Nuwe Testament asook die vroeë Kerkvaders in die Griekse vertaling, die Septuagint, gelees en aangehaal. In die lig van hierdie feit is die vraag na watter teks - Hebreeus of Grieks - as die outoritêre teks van die Ou Testament vir Teologiese interpretasie behoort te geld. Die Nuwe Testament self erken implisiet albei die Hebreeuse en Griekse weergawes daarvan en dit is belangrik vir Teologiese interpretasie om bewus te bly van die onderskeie trajekte van interpretasie wat die onderskeie teksvorme behels, aangesien dit die trajek wat gevolg word noodwendig sal beïnvloed.

Filippus se respons op die vraag van die Etiopiër, 'Sê vir my, asseblief, van wie praat die profeet hier, van homself of van iemand anders?' (NAV) deur by hierdie Skrifgedeelte te begin en die evangelie van Jesus aan hom te verkondig, is 'n belangrike beginsel wat ook in Teologiese interpretasie toeligtingsmoontlikhede het. Teologiese interpretasie van die Bybel is toegespits op die eenheid van die Bybel as kanon - 'n eenheid wat dikwels in die Bybelwetenskappe progressief afwaarts en inwaarts gereduseer word van 'n bybelse teologie tot die onderskeie teologieë van die twee Testamente, tot die teologieë van die individuele korpusse waaruit die Testamente bestaan, tot die teologieë van die onderskeie bronne waaruit die korpusse van die onderskeie Testamente bestaan (Carson 2011:189). Moberly (2011:173) wys daarop dat die verskil in die gebruik en verstaan van die woord teologie tussen wat gerieflikheidshalwe enersyds historieskritiese en andersyds kanoniese benaderings tot die Bybelteks genoem kan word, verband hou met verskille in die algemene benadering tot die teks wat gevolg word. Die hoek waaruit histories kritiese benaderings teologie beskryf, is in terme van die betekenis van die Bybelteks ten opsigte van die wêreld waarbinne dit ontstaan het; met ander woorde, in terme van 'n terugkyk of 'n beskrywing van die wêreld 'agter' die teks. Teologiese interpretasie van die Bybel se invalshoek is om die teologie van die Bybelteks te beskryf ten opsigte van die Christelike geloof as 'n lewende realiteit vir kontemporêre lesers. Met ander woorde, dit is eerder 'n vooruitkyk na die voortgaande geloof in God wat die kanon in die lig van Jesus teweegbring (Moberly 2011:173). 
Teologiese interpretasie van die Bybel is op kennis van God gerig (Vanhoozer 2005:24). Dit let op die teologiese belang van die teks en vra hoe die waarheid waarop die teks gerig is daarin tot uitdrukking kom. Dit besin oor die maniere waarop die Bybelteks God, mensdom en die wêreld verbeeld (Adam et al. 2006:10). Moberly (2011:176-180) plaas Teologiese interpretasie (spesifiek van die Ou Testament) binne die verwysingsraamwerk van verwagtings wat geskep word deur die sosiale aard van kennis in verhouding tot die blywende denke en praktyke van die kerk. Teologiese interpretasie wil met ander woorde integrasie van die Bybelteks en die kontemporêre geloof en lewe bewerk. Juis daarom wil Teologiese interpretasie van die Bybel in die Bybelteks God se spreke hoor (Bartholomew 2005:89-90). Bybelwetenskappe het oor die algemeen elders gefokus, naamlik onder andere op die stem van die gerekonstrueerde historiese Jesus of die redaktor(s) van die teks of die geloofsgemeenskap agter die teks (Green 2007:2; 2011:15-16). Teologiese interpretasie van die Bybel sien die teks egter eksplisiet as kommunikasie - kommunikasie van 'n Goddelike aard met God as 'spreker' sowel as die kommunikasie wat die menslike outeur(s) en/of redaktor(s) in die samestellingsproses van die teks gepoog het om tot stand te bring.

Binne die raamwerk van teologiese interpretasie van die Bybel behels kommunikasie die vestiging van 'n relasie (Vanhoozer [1998] 2009:201-265; vgl. Van Hecke 2011:38). Hierdie hermeneutiese benadering beweeg weg van 'n streng struktureel analitiese benadering tot die teks soos Ricoeur dit voorgestel het om die funksionele dimensie van taal en tekste, naamlik hulle gebruik in kommunikasie en kognisie in die hermeneutiese proses in berekening te bring. Van Hecke (2011:41-42) verduidelik dat, ten spyte van Ricoeur se aandrang daarop dat die teks totaal gedistansieer is van die outeur danksy die aksie van die opskrifstelling van die diskoers (die tweede pool van Ricoeur se hermeneutiek, te wete distanciation ${ }^{18}$ ), dring Ricoeur nietemin daarop aan dat die teks ook in terme van diskoers gedefinieer word - iemand wat iets oor iets aan iemand kommunikeer (Ricoeur 1976:66; kyk ook Viljoen \& Venter 2013). Die gevolg van hierdie insigte is dat interpretasie wat die leser se konteks negeer net so foutief is as die rigiede dekontekstualisering van die outeur en teks. Danksy 'n dubbele bewustheid van die bydrae van die leser sowel as outeur se kontekste ten opsigte van die interpretasie van 'n teks, word die afstand tussen teks en leser erken, maar kan die afstand oorbrug word deur die teks self wat die outeur se kognitiewe inhoud reflekteer en die leser se rekonstruksie daarvan begelei. Die funksie van linguistieke verduidelikings is om die interpretasie van die teksbetekenis soos wat dit aan die leser geopenbaar word, te bekragtig en te staaf (Van Hecke 2011:37). Die linguistieke elemente van die teks word dus eksplisiet bestudeer in terme van die betekenispotensiaal daarvan, met ander woorde in terme van die funksie om kommunikasie en kognisie te genereer (Van Hecke 2011:38). Dit alles gebeur met die verwagting op die tekstuele fasilitering van 'n respons by die leser.

18.Vir meer oor die pole van 'n Ricoeurse hermeneutiek, sien Reese ([1979] 1990), Viljoen (2015); en spesifiek oor distansiasie, Ricoeur (1973).

\section{Die respons}

Teologiese interpretasie van die Bybel ondersoek die rol van die Bybel in die geloofsvorming van mense en die geloofsgemeenskap (Green 2007:2; 2011:15). Ricoeur se invloed op Teologiese interpretasie kan veral gesien word in die belangstelling in, wat Ricoeur figuurlike tekste noem, se invloed op die vorming van menslike subjektiwiteit (vgl. Wallace 1995:14). 'n Mens kan hierdie beginsel in die fokusteks aan die werk sien waar die geloof van die Etiopiese amptenaar deur die werk van die Gees en met behulp van Filippus se uitleg van die Jesaja-teks gevestig word. So hoop Teologiese interpretasie van die Bybel om die vestiging en/of versterking van die geloof van die leser te fasiliteer.

Die handeling van doop in die fokusteks is ook 'n getuie van die krag daarvan om die geloofsgemeenskap se lewe van geloof en aanbidding voor God en mekaar te vorm. Hierdie beginsel kom in die fokusteks tot uitdrukking deur middel van die doopritueel. Die Etiopiese amptenaar se versoek dat hy gedoop word (v. 36), impliseer eerstens dat die doop as ritueel van die kerk deel was van Filippus se verkondiging aan die Etiopiese amptenaar van die evangelie aangaande Jesus. Tweedens is die Etiopiër se navraag oor wat sy doop sou kon verhinder 'n uitdrukking van die geloof wat deur die werk van die Gees en met behulp van Filippus se uitleg van die teks tot stand gekom het (Peterson 2009:296). Handelinge $8: 37^{19}$ het nie in die vroegste manuskripte voorgekom nie (De Villiers 1983a). Die invoeging daarvan verwoord moontlik'n latere doopformulier van die vroeë kerk (Peterson 2009:297). In die vroegste manuskripte word die geloof van die Etiopiese amptenaar egter vanselfsprekend aanvaar en die latere invoeging wil juis uitdrukking gee aan die nóu verband tussen die belydenis van geloof in Jesus as die Christus, die seun van God en die doop binne die verstaansraamwerk van die vroeë kerk.

Dit is hierdie geloofsvormende aspek van die teks, die illokusionêre krag daarvan, wat veral in Teologiese interpretasie van die Bybel aandag kry (vgl. Adam et al. 2006:8). Nog een van Ricoeur se invloede op Teologiese interpretasie van die Bybel kan onderskei word in die gedagte wat dikwels in Teologiese interpretasie aanwesig is, naamlik dat die teks 'n reisplan vir die leser en geloofsgemeenskap daarstel wat nooi tot navolging (vgl. Vanhoozer [1998] 2009:438). In Teologiese interpretasie van die Bybelteks kry die improviserende getrouheid aan die reisplan wat die teks bied, gebalanseer met die onwrikbare kriteria van getroue uitvoering van die imperatief van die teks in die lewe van die leser en geloofsgemeenskap, aandag (Adam et al. 2006:12; Vanhoozer 2006:51-93; [1998] 2009:431-441). Van Hecke (2011:42-43; 2014:74-78) beskryf die hermeneutiese proses as metaforisering. Soos 'n metafoor kognitiewe kartering fasiliteer tussen die bron en teikendomeine, fasiliteer die teks die kognitiewe kartering tussen die betekenis daarvan (wat soos die brondomein in metafoorstudies funksioneer) en die verstaan van die leser se wees-in-die-wêreld (wat in die interpretasieproses soos die teikendomein funksioneer) in glo." Die hofdienaar sê toe: "Ek glo dat Jesus Christus die Seun van God is."' 
terme van die lewensmoontlikhede wat die teks aan die leser bied. Teologiese interpretasie wil hierdie uitnodiging van die teks in terme van die betekenis daarvan wat gedagte- en lewensrigtings tot 'n sekere manier van wees-in-die-wêreld open, ontgin.

In die vreugde waarmee die Etiopiese amptenaar sy reis voortsit, word 'n lewenspatroon, gekenmerk deur vreugde, bespeur wat ' $n$ tema in Lukas-Handelinge is: vreugde as die regte respons op God se handelinge ${ }^{20}$ (Parsons 2008:122). Hoe hierdie vreugde uitdrukking kry in die lewe van die onderskeie lesers en geloofsgemeenskappe is 'n saak van improviserende getrouheid aan die reisplan wat die teks bied. Dit sal uiteenlopend manifesteer in verskillende lesers en geloofsgemeenskappe. Dit word egter gebalanseer met die onwrikbare kriteria van getroue uitvoering van die teksimperatief in die lewe van die leser en geloofsgemeenskap, naamlik dat ' $n$ vreugdevolle respons op die handelinge van God in een of ander vorm gemaak sal word. Teologiese interpretasie van die Bybel is as dissipline doelbewus in diens van die kerk en wil die geloofsgemeenskap veral bystaan in die interpretasie van die Bybelteks ten einde die transformerende krag van die teks in terme van geloofsvorming en dissipelskap te ontgin. As sodanig is dit gerig op die fasilitering van 'n respons van die leser.

Nadat Filippus deur die Gees van die Here weggeneem is sodat die amptenaar hom nie meer kon sien nie, sit hy sy werk voort om die evangelie oral te verkondig (vv. 39 en 40). So is Teologiese interpretasie van die Bybel ook 'n voortdurende taak omdat die ontginning van die rykdom van die evangelie, telkens in nuwe kontekste, 'n voorreg is en nuwe uitdagings aan die voorstanders van Teologiese interpretasie van die Bybel bied.

\section{Samevattende opmerkings}

Teologiese interpretasie van die Bybel bied 'n hermeneutiese verruiming waarbinne meer aspekte van die Bybelteks ondersoek en ontgin kan word. Veral aspekte van die teks wat in ooreenstemming is met die aard van die Bybelteks as Skrif van die kerk asook die illokusionêre krag van die teks. Die Bybel is 'n teologiese geskrif en wil lesers beweeg in terme van die teologiese perspektief van die teks. $\mathrm{Na}$ inleidende opmerkings ten opsigte van Teologiese interpretasie het drie vrae die nadenke rondom die definiëring daarvan begelei: eerstens, Waarom Teologiese interpretasie van die Bybel?; tweedens, Wat is Teologiese interpretasie van die Bybel nié?; en derdens, Wat ís Teologiese interpretasie van die Bybel? Laasgenoemde is ontgin aan die hand van 'n fokusteks, naamlik Handelinge 8:26-40 wat as'n gevallestudie gedien het. Bogenoemde verteenwoordig nie 'n omvattende refleksie op die hele beweging van Teologiese interpretasie van die Bybel nie en is uiteraard nie' $n$ omvattende definiëring van die taak daarvan nie, maar verteenwoordig inleidende gedagtes rondom my eie verstaan van die definiëring daarvan asook die verhouding tussen spesifiek OuTestamentiese wetenskap en Teologiese interpretasie.

\section{Erkenning Mededingende belange}

Die outeur verklaar dat sy geen finansiële of persoonlike verbintenis het met enige party wat haar nadelig kon beïnvloed het in die skryf van hierdie artikel nie.

\section{Literatuurverwysings}

Adam, A.K.M., Fowl, S.E., Vanhoozer, K.J. \& Watson, F., 2006. 'Preface' in A.K.M. Adam et al. (eds.), Reading scripture with the church: Toward a hermeneutic for Theological interpretation, Kindle edn. pp. 7-13, Baker Academic, Grand Rapids, MI.

Allen, R.M, 2011a, Theological commentary: Evangelical perspectives, T\&T Clark International, London.

Allen, R.M., 2011b, 'Theological commentary' in R.M. Allen (ed.), Theological commentary: Evangelical perspectives, pp. 1-9, T\&T Clark international, London.

Bartholomew, C., 2005, 'Biblical theology and Theological interpretation' in K.J. Vanhoozer (ed.), Dictionary for Theological interpretation of the Bible, pp. 88-90, Baker Academic, Grand Rapids, MI.

Bowald, M.A., 2010, 'The character of Theological interpretation of Scripture' International Journal of Systematic Theology 12(2), 162-183. https://doi.org/ International Journal of Systematic
$10.1111 / \mathrm{j} .1468-2400.2009 .00448 . x$

Bowald, M.A., [2007] 2016, Rendering the word in theological hermeneutics: mapping divine and human agency, Routledge, New York.

Briggs, R.S., [2010] 2012, The virtuous reader: Old Testament narrative and interpretive virtue, Baker Academic, Grand Rapids.

Carson, D.A., 2011, 'Theological interpretation of Schripture: Yes, but ...', in R.M. Allen (ed.), Theological commentary: Evangelical perspectives, pp. 187-207, T\&T Clark International, London.

Cheung, M.Y., 2014, 'To be as hermeneutical as possible', in R. Bieringer, et al. (eds), Provoked to speech: Biblical hermeneutics as conversation, pp. 51-68, Peeters, Leuven.

De Villiers, J.L., 1983a, Die Handelinge van die Apostels (Hand 8:37), Kaapstad, NG Kerkuitgewers, Kaapstad.

De Villiers, J.L., 1983b, Die Handelinge van die Apostels (Hand 8:30), NG Kerkuitgewers, Kaapstad.

Fowl, S.E., [1998] 2008, Engaging Scripture: A model for theological interpretation, Wipf \& Stock, Eugene, Oregon.

Green, J.B., 2007, 'The (re)turn to theology', The Journal for Theological Interpretation $1(1), 1-3$.

Green, J.B., 2011, Practicing Theological interpretation: Engaging biblical texts for faith and formation, Baker Academic, Grand Rapids.

Green, J.B. \& Meadowcroft, T. (eds.), 2013, Ears that hear: Explorations in Theological interpretation of the Bible, Sheffield Phoenix Press, Sheffield.

Heringer, S., 2013, 'The problem of "history" in recent theological commentary' in J.B. Green \& T. Meadowcroft (eds.), Ears that hear: Explorations in theological interpretation of the Bible, pp. 26-42, Sheffield Phoenix Press, Sheffield.

Illocutionary force, nd., viewed 21 February 2017, from http://ccat.sas.upenn. edu/ haroldfs/dravling/illocutionary.htm

Jenkins, H.P., 1989, 'Who is the "suffering servant" in Deutero-Isaiah?', unpublished position paper in partial fulfilment of the requirements for the A.F.T.S in Old Testament.

Jeanrond, W.G., 1991, Theological hermeneutics: Development and significance, Macmillan Academic and Professional Ltd, London. https://doi.org/10.1007/9781-349-09597-1

Lessing, G.E., [1777] 2005, 'On the proof of the spirit and of power' in G.E. Lessing (ed.), Philosophical and theological writings, pp. 83-88, transl. \& ed. H.B. Nisbet, Cambridge University Press, Cambridge.

MacArthur, J.F., 1973, Acts 7:54-10:33 (Bible book studies): The faith that does save, viewed 5 December 2016, from http://www.gty.org/MediaPlayer/sermons/1727

Moberly, R.W.L., 2009, 'What is theological interpretation of Scripture?', Journal of Theological Interpretation 3(2), 161-178.

Moberly, R.W.L., 2011, 'What is theological commentary? An Old Testament perspective', in R.M. Allen (ed.), Theological commentary: Evangelical perspectives, pp. 172-186, T\&T Clark International, London.

Moyaert, M., 2014, 'Paul Ricoeur on Biblical hermeneutics', in R. Beringer et al. (eds.), Provoked to speech: Biblical hermeneutics as conversation, pp. 27-50, Peeters, Leuven.

Nathan, E., 2014, 'Beyond the desert: re-engaging the Bible today', in R. Beringer, et al. (eds.), Provoked to speech: Biblical hermeneutics as conversation, pp. 15-25, Peeters, Leuven.

Parsons, M.C., 2008, Acts, Baker Academic, Grand Rapids.

Peterson, D.G., 2009, The Acts of the apostles, Wm. B. Eerdmans Publishing, Grand Rapids.

Reese, J.M., [1979] 1990, 'Can Paul Ricoeur's method contribute to interpreting the book of Wisdom?', in M. Gilbert (ed.), La sagesse de l'Ancien Testament, pp. 384-396, Leuven Úniversity Press, Leuven.

Ricoeur P., 1973, 'The hermeneutical function of distanciation', Philosophy Today 17(2), 129-141. https://doi.org/10.5840/philtoday197317233 
Ricoeur, P., 1976, Interpretation theory: Discourse and the surplus of meaning, Texas Christian University Press, Fort Worth.

Treier, D.J., 2008, Introducing Theological interpretation of Scripture: Recovering a Christian practice, Kindle edn., Baker Publishing Group, Grand Rapids, MI.

Van Hecke, P., 2011, From linguistics to hermeneutics: A functional and cognitive approach to Job 12-14, Brill, Leiden.

Van Hecke, P., 2014, “"Do you understand what you are reading?" (Acts 8:30): On the place and role of exegesis' in R. Bieringer, et al. (eds.), Provoked to speech: Biblical hermeneutics as conversation, pp. 69-83, Peeters, Leuven.

Vanhoozer, K.J., 2005, 'What is Theological interpretation of the Bible?', in K.J. Vanhoozer (ed.), Dictionary for Theological interpretation of the Bible, pp. 19-25, Baker Academic, Grand Rapids, MI.

Vanhoozer, K.J., 2006, 'Imprisoned or free?: Text, status and Theological interpretation in the master/slave discourse of Philemon', in A.K.M. Adam, et al. (eds.), Reading Scripture with the church: Toward a hermeneutic for Theological interpretation, Kindel edn., pp. 51-93, Baker Publishing Group, Grand Rapids, MI.

Vanhoozer, K.J. 2008, 'Introduction: What is theological interpretation of the Bible', in K.J. Vanhoozer, (ed.), Theological interpretation of the Old Testament: a book-bybook survey, pp. 15-28, Baker Academic, Grand Rapids, MI.
Vanhoozer, K.J., [1998] 2009, Is there a meaning in this text? The Bible, the reader, and the morality of literary knowledge (Landmarks in Christian Scholarship), Kindle edn., Zondervan, Grand Rapids, MI.

Vanhoozer K.J., 2014, Faith speaking understanding: Performing the drama of doctrine, Westminster John Knox Press, Louisville.

Viljoen, A. \& Venter, P.M., 2013, 'An exploration of the symbolic world of Proverbs 10:1-15:33 with specific reference to "the fear of the Lord"', HTS Teologiese Studies/Theological Studies 69(1), Art. \#2008, 6 pages. https://doi.org/10.4102/ hts.v69i1.2008

Viljoen, A., 2015, 'The structuring considerations of a Ricoeurian hermeneutic employed in a reading of Proverbs 14:2'. HTS Teologiese Studies/Theological Studies 71(3), Art. \#2849, 7 pages. https://doi.org/10.4102/hts.v71i3.2849

Viljoen, A., 2016, 'Spiritual formation and the nurturing of creative spirituality: A case study in Proverbs', Verbum et Ecclesia 37(1), a1534. https://doi.org/10.4102/ ve.v37i1.1534

Viljoen, A., 2017, "n Hermeneutiek vir teologiese interpretasie van die Bybel: metodologiese besinning, HTS Teologiese Studies/Theological Studies, Ingedien om gepubliseer te word.

Wallace, M.I., 1995, 'Introduction' in M.I. Wallace (ed.), Figuring the sacred: religion, narrative and imagination, transl. D. Pellauer, pp. 1-35, Fortress, Minneapolis. 